\title{
Absence of Basic Public Management Breeds Extreme Poverty: The Case of Nigeria and Other Developing Countries
}

\author{
Felix F. Barikor, Ph.D* \\ Assistant Professor of Public Administration, French, Office and Information Management, River State University, Port \\ Harcourt, Nigeria
}

*Corresponding Author

Felix F. Barikor

\author{
Article History \\ Received: 16.10 .2020 \\ Accepted: 02.11.2020 \\ Published: 09.11.2020
}

\begin{abstract}
This paper is trying to introduce a new concept in public administration which research shows is not effectively implemented in most countries where extreme poverty is endemic including Nigeria. The concept is known as "Effective Basic Public Management" which is the auto-pilot on which governments are run in developed societies. Nigerian public managers do not understand that the basic functions of government have to be performed on a daily basis just as they run their various families which are the nucleus of the larger society. Many reasons have been attributed to for Nigeria's lingering administrative failure in all ramifications since independence in 1960 but it all points to one thing, poor and unpatriotic leadership which have simply ignored the rudiments of effective basic public management as practiced in developed countries. The paper is in two parts, part one discusses effective basic public management and strong institutions and how they are created, while part two defines the concept of basic public management and other related issues including maintenance.
\end{abstract}

Keywords: public, developed societies, Poverty, Developing Countries.

\section{INTRODUCTION}

The focus of this brief paper is the introduction of the new concept called "effective basic public management" in an attempt to draw the attention of readers to a surprising observation made about the running of governments in Nigeria (i.e., federal, states, cities, towns, villages etc.) while conducting a post-graduate research in public administration in the Mid-west State of Iowa, USA between the year 1999 and 2000. The surprising observation is, the fact that "effective basic public management" is not implemented in Nigeria. Essentially, the study was based on a research carried out from 1999 to date while working on a book project [1]. Current issues discussed in the paper are derived from telephone calls, radio, television and of course social media e.g. Recent General Elections in Nigeria, 2019. The findings are very interesting because many people still wonder why the Nigerian government and other developing countries are struggling to perform basic functions of government taken for granted in developed countries [1].

While the daily and perpetual diligent execution of the "basic functions of government" [2] which include creating the basic institutions of government, programs and services and running them consistently resulting in a livable condition for the citizens in America, in Nigeria and other developing nations on the contrary, most basic functions of government are not being executed daily and continuously in addition to non-creation of most of the basic institutions of government, programs and services. This is why there is insufficient supply of water, electricity, paved roads, paved streets, drainages, public conveniences, health institutions and also insufficient placement places in schools, colleges and universities. Let us mention in passing that every year about two million young Nigerians pass out of high schools and about one and half millions take the university matriculation examinations out of which about half are admitted according to JAMB, Nigeria's government agency responsible for the conduct of entrance examinations into the nation's tertiary institutions. That is to say that deliberate efforts need to be made to replicate all basic institutions of government, programs and services so that the government can perform its basic functions in all the autonomous localities in the

Copyright $\odot 2020$ The Author(s): This is an open-access article distributed under the terms of the Creative Commons Attribution 4.0 International License (CC BY-NC 4.0) which permits unrestricted use, distribution, and reproduction in any medium for noncommercial use provided the original author and source are credited. 
country and the research shows that funding is not the problem but avoidable wastages and outright theft of public resources may be blamed [1].

For the purpose of this paper, the notion of public administration and public management may be used interchangeably even if many public administrators tend to argue that public administration deals mostly with policy formulation, programs and services creation while public managers essentially deal with the implementation and execution of the formulated policies, programs and services so created by administrators (www.onlinemasters.ohio.edu/blog/). Readers so interested in the differences between public administration and public management may look them up at www.onlinemasters.ohio.edu/blog/ or other authors on that topic.

\section{PRELIMINARY ANALYSIS OF EFFECTIVE BAISC PUBLIC MANAGEMENT?}

Effective Basic Public Management by Public Administrators in any developing nation is the Missing Link in the building of strong institutions as the foundation of the Development Agenda in that nation including Nigeria and the other developing nations with endemic poverty. Nigeria's public managers do not seem to understand that the whole concept of running a government is based on the 'broomstick theory' which says that broomstick breaks easily as a single strand but almost unbreakable as a bunch. That is, resources are pooled together and applied to run the affairs of the state on a daily basis as opposed to letting everyone struggle on his own with his individual resources for his daily subsistence. Thus, lack of effective daily basic public management by public administrators in Nigeria has given rise to the characterization of Nigeria as a failed state by public management experts who are used to societies where effective daily basic public management is the way of life [1].

The creation of public good for the benefit of all or society has always been the main concern of public administrators and public administration's theorists. Most citizens would prefer to be free riders and not contribute towards the making of public good and that was the reason why the need of public administration arose. Writing under the subject of "Social Capital and Institutional Success," Robert Putnam uses several games theories such as David Hume's parable, "the tragedy of the commons," "a public good," "the prisoner's dilemma," to illustrate how what he calls the "dilemma of collective action" demonstrates the unwillingness of individuals to cooperate for public good even if such cooperative action would have delivered a happier outcome for everybody concerned [3]. It is just to emphasize the need for collective action and the pooling of resources for the common good of the society which is the main goal of public administration.

Non-implementation of effective basic public management in Nigeria was brought about by corruption itself. Corruption weakens the institution which actually brings about even more corruption which is the immediate factor responsible for the failure of Nigeria as a nation state [4]. The characterization of Nigeria as a failed state has unfortunately been an embarrassingly recurring incident at every international conference or forum on development for several years now and yet the political leadership and public managers of the country appear to have no clue as to the solutions to the problems [5]. The government's only solution for now is to demonize any analyst or commentator who dare say the truth and, yet any first-time visitor from an advanced society can only deride Nigerian public officials each time they mention the building of strong institutions because without effective basic public management no strong institutions can be built. Strong institutions around the world are created by effective basic public management which is based on the strict implementation of public policies and programs and the strict enforcement of basic law and order [1].

Nigeria is presently unable to perform the most basic functions of government such as the protection of life and property, provision of basic utilities like electricity, water, housing, roads maintenance and the provision of basic services such as refuse collection, public convenience, the management of vehicular traffic in towns and cities and the maintenance of common law and order in a society where lawlessness and impunity are exhibited everywhere one goes which are the real foundations of our weak or failed institutions. Every Nigerian is a government unto himself because he provides all his basic needs by himself including the building and maintenance of his street, provision of electricity and water just to name these few [1].

Although everybody knows that what Nigerian political leaders run as government is only the cabinets from federal to local governments, agencies and parastatals, they are still unable to conduct a proper election to fill these cabinets from independence till date. The most recent general elections of February 23 and March 9, 2019 in which scores were killed by the combined actions of the army, air force, navy and police who were employed by the government in power as thugs stealing or destroying electoral materials and kidnapping and manhandling electoral officers and opposition party members are still very fresh in our memory (Chanel TV, March 10, 2019, monitored online).

The basic public management, the real government which creates wealth or the enabling environment for wealth creation or production does not actually exist. Consequently, each time elections are due to be conducted the crisis that 
usually arise would nearly always bring the country to the precipice like the example mentioned above and it had already resulted into a bloody civil war (1967-1970) following a pogrom against Southerners resident in the north in which thousands were massacred. The failed electoral processes resulted into violence especially in the west which was eventually followed by the January 1966 coup and counter coup d'état, pogrom targeting southerners in the north and several military interventions in politics in the past and yet the political leadership appears to have learned nothing from those past national tragedies. Besides, it is ridiculous for public officials to be talking of job creation without even realizing that an effective basic public management alone is capable of providing jobs and even more opportunities for further job creation that will nearly exhaust the available job-seeking population in the country today. In other words, a systematic daily effective basic public management is capable of providing solutions to most of Nigeria's systemic problems of today [1].

Some of the major systemic ills plaguing the Nigerian society today include ineffectiveness of government resulting into general lawlessness and the failure of government institutions. This in turn brings about extreme poverty, corruption, armed robbery, kidnapping, insurgency, lawlessness and general insecurity. This widespread criminality is blamed on poverty and poverty itself is blamed on corruption, a vicious cycle which is responsible for a large population of unemployed people especially the youth and the able-bodied men and women due to the inability of the Nigerian state to create jobs or the enabling environment for private enterprises to do so or even providing basic public assistance to the unemployed and the needy. Very recently in Rivers State, one of cultists who accepted the amnesty offered by the government confessed that he was sixty five years old and that he joined the criminal gang in Kalabari region as a means of survival when he was about forty years old. This case is very interesting because in the United States he would have qualified for public assistance as a senior citizen ten years ago but in Nigeria there is no public assistance of any kind [1]. The next section will define in detail the concepts of effective basic public management but let us start by understanding what strong institutions are all about.

\section{DEFINING STRONG INSTITUTIONS IN PUBLIC MANAGEMENT AND HOW THEY ARE CREATED}

Strong institutions are the foundations on which good governance are built. It is common knowledge that Western political leaders and diplomats often advise Nigerian political leaders to create or build strong institutions and not strong personalities for the purpose of good governance but it is uncertain whether any of our political leaders have dared to ask them how the strong institutions can be created and without strong personalities. Thus, despite all the years of interactions with the Western political leaders and diplomats our political leaders continue to grope in the dark as far as the creation of strong government institutions for good governance is concerned. What then are these strong institutions?

When we talk of institutions, we are referring to every establishment be it public or private but in public management we are particularly referring to public institutions. Both public and private institutions are created or built with human and material resources. Government ministries, departments, national organizations and agencies are very common examples of public institutions while private industrial complexes, enterprises, international organizations and non-profit organizations are common examples of non-governmental organizations.

How do we build strong institutions? According to International Development Association (IDA), The World Bank's Fund for the Poorest 2016:

"Good governance and strong and accountable institutions are crucial for poverty reduction and development effectiveness. That is why International Development Association (IDA) actively supports governments to become more transparent, more accountable to citizens, less susceptible to corruption, and better in delivering services. IDA, the World Bank's fund for the poorest, works with ministries, agencies and departments of the executive branch on managing public institutions and finances better, and on broader governance issues, including the legislature and judicial branches and other institutions that promote accountability and greater engagement with society." (www.worldbank.org/ida), an online resource.

As stated earlier, institutions are built with human and material resources and it is the human resource component of institutions that is required for building a strong institution. In other words, building strong institutions does not imply building institutions with earth-quake proof or bullet-proof materials but rather, it emphasizes the development of human capacity to the highest level of efficiency and integrity aimed at accountability in order to achieve effectiveness in basic public management and effective service delivery.

What played out recently on the American public management scene between the judiciary and the newly elected $45^{\text {th }}$ president of the United States, Mr. Donald Trump is a very good example of how strong institutions function under international best practices. President Donald Trump issued an executive order to ban seven Muslim majority countries from entering the United States but the judiciary ruled against his decision on the ground that such an executive 
order was unconstitutional and everybody obeyed the court verdict but in Nigeria the presidents pick and choose which court orders to obey. Donald Trump and his new government know the consequences of disobeying the court unlike Nigeria where individuals are stronger than the institutions (NPR, American Public Media, 2017). For instance, the eyes blinking contest that took place between the Nigerian Senate and the Controller-general of Custom in 2018 and we all watched to see whose eyes will blink first. The controller-general of Custom had his way as it is always the case in Nigeria. The question is, when will Nigeria have the institutions whose rules and regulations individuals cannot bend?

When North American and Western European leaders and diplomats advise our political leaders to build strong institutions and not strong men, they are actually talking about building a positively strong human resource base rather encouraging authoritarian leadership and dictatorship that are in no way accountable to the people. It is the positively strong leadership that drives strong institutions for sustainable development. Positively strong leadership is incorruptible, selfless, very effective and does not bend the rules for personal interests. Positively strong leadership does not engage in public management activities that are tantamount to conflict of interests which is a common practice in Nigeria. For instance, during the recently conducted general elections in Nigeria, the president was accused of appointing blood relatives to play key roles in the elections which was quite unethical to say the least.

This does not in any way undermine the need for building materially strong physical establishments or institutions because no matter how strong the prison guards are, there will still be frequent jailbreaks if the correctional facility is not fortified according to the level of security required for its inmates. Frequent collapse of public infrastructures especially public highways are indications that not only are our superstructures weak, our infrastructures are equally weak if not weaker. In other words, it would take a strong superstructure to build a strong infrastructure.

Therefore, the building of strong institutions depends on the training and development of the human resources to imbibe the culture of transparency, accountability to citizens, incorruptibility, efficiency and competence in their areas of specialization in order to be effective in delivering better services to the various institutions of government and the general public. This is how strong institutions are built and the efficiency and effectiveness of the human resource component of the institution can only be verified through effective service delivery as demonstrated in countries where effective basic public management is the way of life.

For the avoidance of doubt, some of the government institutions whose weaknesses resulted in the weakness of Nigeria as a state are the regulatory agencies and departments such as the ministry or department of justice, Central Bank of Nigeria, Nigerian National Petroleum Corporation, National Communication Commission, Nigeria Electricity Regulatory Commission, Standard Organization of Nigeria, Nigerian Food and Drug Administration, Nigerian Police, Military and Para-military, local governments, cities, towns and village councils. If these institutions had functioned efficiently and effectively, Nigeria would not have fallen into the category of failed states [1].

\section{DEFINING THE CONCEPTS OF BASIC PUBLIC MANAGEMENT}

What is basic public management? This is the practice of creating all basic public institutions, services and programs and running them efficiently and effectively on a daily basis and in perpetuity (i.e., non-stop). It is based on the broomstick theory of collective efforts by pooling resources together and it is the engine room for wealth creation and production. Basic public management is the auto pilot on which government runs in developed countries around the world. The evidence of lack of basic public management abounds everywhere in Nigeria especially to first time visitors from advanced countries where basic public management is taken for granted. The first and the most common evidence of lack of basic public management are the ruthless and uncontrollable crowd of touts in our airports and motor parks, reckless motorists, abandoned broken down vehicles on our roads and disorderly pedestrians on our roads (crossing highways recklessly) and the evidence of poor or none maintenance of facilities visible at the entry of our airports, and from these visible evidence of public management lapses resulting into chaos and decay, the foreigner quickly forms his first impression about our country and first impression can only be formed but once Barikor [1].

Basic public management is based on four basic principles, namely, (a) the principle of self-funding through service provision, (Based on the broomstick theory) (b) the principle of maintenance of infrastructures and programs in perpetuity, (c) the principle of deliberate replication of services, infrastructures, programs and institutions in every autonomous locality and (d) the principle of effective and strict enforcement of law and order, diligent justice administration, policies, services and programs in perpetuity [1].

\section{Summary of the Four Basic Principles of Effective Basic Public Management (a) The principle of self-funding through service provision}

This is the first and the most important principle of basic public management. It is based on the broomstick theory which emphasizes the pre-eminence of resource pooling. (The broomstick theory says that it is very easy to break a broomstick but almost impossible to break a bunch of broomsticks depending on how large that bunch is). It is the real 
foundation of basic public management. It enhances production and helps to create wealth. The principle is based on the ground that the government pools public resources together in order to provide some essential services and programs and charges service fees or taxes on them which enables the government to recycle the funds through the continuous provision of such services. This actually provides the base of the auto pilot which keeps the government running in perpetuity. Unfortunately, this is one of the weakest links in the administration of the Nigerian public management system and other developing nations. Examples of such services includes electricity, water, refuse collection, public conveniences (Toilets), road construction and maintenance, registration of birth and death, registration of vehicles, management of vehicular traffic and parking spaces, issuance of driver's license, identity cards, public institutions and international passport to mention these few.

\section{(b) The principle of maintenance of infrastructures and programs in perpetuity}

The running of government is a continuous process and this process cannot continue if infrastructures and programs of government are interrupted or not maintained each time there is a change of government. This largely explains why the Nigerian state is constantly referred to as a failed state. Not only are most infrastructures of government and programs not created but even those that have been created have disappeared in time due to lack of maintenance and policy continuity. In normal situations, programs and infrastructures of government could only be halted or disrupted by natural disasters or civil conflicts for them to cease to exist but in Nigeria they are either never had been created in the first place or were created but disappeared due to lack of maintenance and continuity following the change of leadership.

So, Nigeria needs to imbibe the culture of maintenance of infrastructures and programs in perpetuity in order to attain sustainable development. A very recent and prominent example of lack of policy continuity was reversed following the redemption of the pledge that the present president of Nigeria made to the pioneer champions of the World Junior World Cup in 1985. The pledge was not fulfilled by the General Babangida's administration which took over government from General Buhari in 1985 in a coup d'état. Soon after a new government came into place, one of its first priorities is to distant itself from the policies and programs of the previous government. Even the current president did exactly that by reversing the presidential policy of his predecessor, Dr. Goodluck E. Jonathan which created six Federal Universities to augment the current shortages of admission spaces for aspiring undergraduates and graduate students. Remember that this is one of the critically important sectors where Nigeria currently fall short. Several other reversal actions were also taken especially with appointments and construction projects too numerous to mention and Nigeria will only cease to be a failed state when continuity in perpetuity is fully implemented.

\section{(c) The principle of deliberate replication of services, infrastructures, programs and institutions in every autonomous locality}

To understand this principle one needs to imagine a small town or village that was completely obliterated by war or natural disaster such as thunderstorm, hurricane or tornado which is being rebuilt from the scratch. Everything that makes life worth living has to be put in place like implementing the US Marshall Plan after World War II in 1945. Basic public management has every autonomous locality as its smallest functional unit for operational purposes. An autonomous locality can be as small as a hamlet, a village, a small town, a town or a city or even housing estate developments. The principle is based on the fact that as long as the autonomous locality has a population that is not within the reach of government services, infrastructures, programs and institutions, the community in that locality has to be provided with all those amenities through the policy of deliberate replication.

This policy of deliberate replication of services, infrastructures, programs and institutions has been known to result into a win-win situation where large towns and cities with over-stretched services, infrastructures, programs and institutions benefit from the excess capacity of amenities of neighboring autonomous locality. For instance, studies show that small towns or communities in the United States supply their excess water or electricity to neighboring large cities where such services are over-stretched. Residence of large cities with crowded public services have also been known to have been going to small towns for services such as vehicle inspection, driving test, attending schools and colleges to name these few. The argument here is not that these services and programs do not exist in Nigeria or the other developing countries, but the problem is that the government does not make deliberate efforts to provide them sufficiently, for example, electricity, water, paved roads, schools, colleges, universities, public conveniences, hospitals and other institutions. As mentioned earlier, it is not due to lack of funding but rather inefficient management of the available resources.

Finally, autonomous locality in this case can be defined to include neighborhoods, housing estates, hamlets, villages, towns, cities, counties and various institutions. It is a common knowledge that these autonomous localities lack most of the services, programs and institution that make life worth living in Nigeria and other developing nations unlike developed societies. The result of this is that every autonomous locality which is like an independent city-state on its own thanks to the deliberate replication of all state services, infrastructures and institutions which include basic utilities like electricity, water, sanitation services (refuse collection and disposal and the provision of public toilet facilities), paving of 
roads and streets, postal services, schools and colleges, hospitals or health centers, libraries, town halls, shopping malls, police departments, secretariat services with clerks for public records keeping (birth and death registry, issuing of identity cards and licenses etc.), just to name these few, promotes the wellbeing of people in developed countries but serves as incubator for the extremely poor people in developing countries where such services and programs do not exist.

\section{(d) The principle of effective and strict enforcement of law and order, diligent justice administration, policies, services and programs in perpetuity}

This is the weakest link in the management of Nigeria's developmental agenda. The Nigerian public management system is extremely weak, ineffective and very incompetent in the enforcement of law and order including diligent administration of justice, policies, services and programs. This principle is completely absent from the Nigerian public management systems and that is the major problem besides the non-creation of basic public services and programs. The present Nigerian political leaders and public managers or administrators do not believe in the principle of continuity because of corrupt tendencies. Continuing or maintaining previous government policies, services and programs do not put large sums of money into the hands of public managers and so they have no incentive or motivation to do so. They are rather motivated to formulate their own policies and create their own services and programs so that they can earn large sums of money from the award of contracts. This is exactly why Nigeria's failure as a state is directly linked to the cankerworm called corruption. This is the fact and no amount of denial or blackmail by current public managers can wish away this empirical fact. Nigeria will cease to fail as a state when effective and strict enforcement mechanisms are put in place for maintenance of law and order, diligent justice administration, policies, services and programs in perpetuity after the creation of such basic public management policies, services and programs where they do not presently exist.

The Nigerian public is fully aware of the fact that this is the weakest link in the Nigerian public management system and that explains the enthusiasm with which they welcomed the government of retired Major-General Muhamadu Buhari. However, almost four years after his government took over from the government of Dr. Goodluck Ebele Jonathan, Nigerians are now doubtful whether this was the strongman they were all looking up to for strict enforcement of law and order and to put an end to lawlessness, impunity, official corruption and enable state institutions to run efficiently and effectively. The disappointment of Nigerians is not without a good cause. For one thing, Nigerians see some individuals they perceive to be the very epitome of corruption working with the president both in his cabinet and his party, the All Progressive Congress, (APC). They are also so aware of how the Nigerian National Petroleum Corporation (NNPC) and Independent Petroleum Marketers continued to disobey his government directives by hording and selling petroleum products even higher than it had ever happened in the country. Apart from being the longest fuel scarcity the country had ever known (June 2015 to June, 2016), the marketers were even more emboldened than ever by raising their pomp price of petrol as high as three hundred and fifty Naira per liter (\#350.00) right at their pumps in the petrol stations. This had never happened before. At the same time, the exchange rate of the Naira also went as high as five hundred and twenty-five Naira (\#525.00) for an American Dollar for the first time according to a Radio Nigeria monitored from Port Harcourt on February 20, 2017 (98.5, Treasure FM. 3PM South-South News), an event no older Nigerian alive had ever witnessed in his life time.

Besides, relieve materials meant for our unfortunate internally displaced compatriots in the North East are being sold in the open markets in the Northern part of the country resulting in the flashing of the kind of images of skinny and bonny children suffering from extreme malnutrition reminiscent of the Nigerian Civil War malnutrition crisis or the Ethiopian famine crisis of the 1980s which prompted the USA United Artists for Africa to sing the famous "We Are the World" to raise fund for Ethiopia, being flashed on international television stations like Aljazeera and BBC TV monitored in Port Harcourt on September 29, 2016. The theft of the relieve materials are blamed largely on the officials of the Federal Government agency called National Emergency Management Agency (NEMA) which is directly under the office of the president. All these are happening in addition to the "budget padding" scandal that rocked the national assembly earlier which is controlled by the president's ruling party, the APC. Finally, the nepotism and tribalism openly displayed by the president himself in all appointments, which are the worst forms of corruption, together with the openly rigged recent general elections 2019 sponsored by the president through his right hand men like Tinubu and Amaechi using all the armed forces at their disposal to cause destruction and deaths in Lagos, Port Harcourt and other parts of Nigeria (Author personally monitored the elections by phone calls, radio, television and social media from Washington DC on February 23, 2019 and March 9, 2019), are clear indications that "The beautiful ones are not yet born!"

The question some Nigerians will be pondering with trepidation at this point is, if corruption, lawlessness and impunity are so blatantly exhibited under our supposedly master-disciplinarian, what is going to happen after him? Will the recent re-launching of War Against Indiscipline (WAI) tagged "The Change Begins With Me" do the trick? I pause for an answer. 
Effective basic public management should also extend to all public institutions like ministries, departments and agencies (MDA) and parastatals such as the Central Bank of Nigeria or the Nigerian National Petroleum Corporation (NNPC) or state institutions like the Braithwaite Memorial Specialist Hospital in Port Harcourt. In addition, effective basic public management ensures that private organizations and agencies are diligently supervised and regulated according to the laws of the land. However, the situation in Nigeria is nothing short of absolute anarchy and this is quite understandable in a country where basic public management is completely absent. In other words, public institutions need to function properly and effectively before they can even spot malfunctioned private institutions to supervise and regulate or can a blind lead a blind?

Looking at the general management failure and inefficiency that characterize the Nigerian public sector, one is bound to ask the question whether there is anything like job description in the Nigerian labor law. Are public employees aware of the basic functions of the positions they occupy? Or are there no performance measurements or benchmarks aimed at achieving the goals and objectives of such positions? In other words, are there any measures put in place to ensure that public employees perform the essential functions of their jobs? If the answer to the question is yes, then at what point was the effective implementation of basic public management omitted or undermined?

Coming to the issue of basic public management again, what is the job description of a mayor or a local government chairman in Nigeria? Protection of life and property not guaranteed, no welfare safety net for the needy, no electricity, no water, no public conveniences, paved roads ridden with potholes where they exist, unpaved roads not graded, no drainages or gutters, refuse not collected or poorly collected with filth everywhere, vehicular traffic not managed with everybody driving recklessly and in most cases against on-coming traffic, broken down vehicles abandoned in the middle of the roads with impunity or repaired right on the road, long queues of customers at all the ATMs and bank tellers in banking halls nationwide while banks are literary extorting their customers with impunity as if there is no central bank, all the telephone companies are busy robbing the entire Nigerian population including the socalled political leadership and embarrassing them with unsolicited calls and text messages as if the Nigerian communication sector has no regulatory agency, the list is endless and yet public administrators of these MDAs, mayors and local government chairmen reign and go at the end of their tenure. They are even unable to collect taxes or generate revenues to run their organizations or government. All they do is receive money from oil companies through the unitary government in Abuja, budget money and share it in the name of unimplemented contracts, salaries and allowances.

As far back as in the 1980s one Professor W. Feuser from Germany of the University of Port Harcourt used to tell the students that since he came to Nigeria, he has been hearing the politicians discussing how to share the national cake but they never discuss how to bake the national cake. This is the only country in the whole world where the government just contract experts (oil companies) to extract natural resources (oil and gas), sell and distribute the proceeds for more than fifty years now without any serious effort to create any wealth or produce anything or create the enabling environment for wealth creation. That is why even the provision of essential amenities as basic as electricity, water and roads are still extremely inadequate. Nigeria's public managers do not even know how to generate revenues apart from receiving and distributing oil and gas proceeds. This is why many states and local government councils are presently unable to pay salaries let alone embarking on any capital projects since the collapse of the price of petroleum resources. What a wonderful country!

\section{Definition of Effective Basic Public Management}

Effective Basic Public Management-This is the practice of creating and running all public basic institutions, services and programs efficiently and effectively on a daily basis and in perpetuity. This concept was discovered in course of a comparative study of the workings of the American and the Nigerian public management systems carried out between 1999 and 2001 to find out why the former system was performing excellently well while the latter had resulted in a failed system where nothing appears to be working correctly. The concept is clearly defined in this section. The nomenclature of the concept is actually a description of the operating public management systems in North America and Western Europe and it constitutes the auto-pilot on which modern government of developed countries runs. It is also the basis of strong institutions which every developing country is trying to build in order to attain sustainable development.

\section{Concept and Definition of Maintenance}

Maintenance is the pivot on which basic public management revolves. The Oxford Dictionary (2014) defines maintenance as "the repairs, painting etc. that are necessary to keep something in good condition" and as "the act of making a state or situation continues". It further states that to maintain is "to make something continue in the same way or at the same standard as before".

During the research, three types of maintenance which are sometimes referred to as rehabilitation were found to be operational in Nigeria. These were (a) restoration maintenance, (b) remodeling or improvement maintenance, (c) rebuilding or reconstruction maintenance. Let us briefly describe these three maintenance models. 
It is the restoration maintenance that fits into the classical definition of maintenance. It involves repairs and repainting aimed at restoring something to its original state. The study reveals that more than $90 \%$ of public and private properties, structures and institutions do not undergo any kind of scheduled and regular maintenance. In most cases, the structures or facilities are neglected until they deteriorate to the condition of complete disrepair before embarking on a complete rebuilding or reconstruction. Restoration maintenance is the most cost-effective or least expensive of the three types of maintenance. Unfortunately, this is the least popular form of maintenance in Nigeria because as noted earlier, public managers have no incentive for implementing it.

Remodeling or Improvement Maintenance is an effort aimed at restoring the original state of something by modifying its original form slightly. For instance, un-partitioned French Windows in a house can be replaced with a partitioned window or replaced with an encasement window. Again, the roof of a house can be changed from the oldfashioned galvanized roofing sheets popularly known as "Cameroon Zink" to a modern step-tiles roof. The floor of the house can also be tiled instated of the old-cemented floor. This is more cost-effective or less expensive than rebuilding or total reconstruction.

Rebuilding or Reconstruction as stated earlier is embarked upon once the object or something has deteriorated beyond repair. Unfortunately, this is the most common type of maintenance in Nigeria and it is the most expensive of all the three types of maintenance models available. The planning and the execution of this type of maintenance is even more expensive than building a new structure or buying a new object because it necessarily involves the cost of disposing of the old structure or object before building the new one or installing it. The only reason why this model comes under the nomenclature of maintenance is that it is reconstructed or rebuilt as a replacement on the very position of the irreparable structure or the deteriorated object, for instance, roads, bridges or houses. The key question here is, why do Nigerian public managers prefer this most expensive maintenance model? Research shows that public managers benefit personally from embarking on brand new projects rather than maintaining the existing structures or facilities put in place by previous managers. As earlier noted, corruption may be a motivating factor for maintenance failure in Nigeria.

\section{CONCLUSION}

This study was based mostly on extensive traveling and observations in many states in Nigeria and public media like radio and televisions monitored over a long period of time. The study found out that individuals spend more on electricity, water, construction and building of their own roads and streets and traveling abroad for further education. That is to say, if the government pools all the available resources through minimum contributions and implements the effective basic public management effectively so that everybody has access to them, the level of poverty, criminality and diseases will be greatly reduced like the situation in developed countries. The governments of Nigeria and the other developing nations should realize that the running of the various cabinets of government from the federal, provincial, state, county or local government, city, town and village governments are quite different from the day to day running of programs, institutions and services to the people which is the real government. Implementation of the effective basic public management consistently and in perpetuity will definitely minimize poverty to the barest minimum in the underdeveloped societies around the world.

\section{REFERENCES}

1. Barikor, F. F. (2017). Current Trends in Public Management in Nigeria. Published by FIBAG International Services LTD, Port Harcourt.

2. Wilson, W. (1941). "The Study of Administration.” Political Science Quarterly. 56(2),197-222. (First Published 1887). (Online Resources).

3. Putnam, R. D. (1993). Making Democracy Work-Civic Traditions in Modern Italy. New Jersey: Princeton University Press.

4. Keyamo, F. (2014). “Corruption Failed Criminal Justice System Fuelling Terrorism.” Online: Facebook/Channels Television. September 16, 2014.

5. Obe, E. (2009). "Nigeria is a failed state, says ex-minister". The Nigerian Punch Newspapers on May 8, 2009. Lagos, Nigeria. 